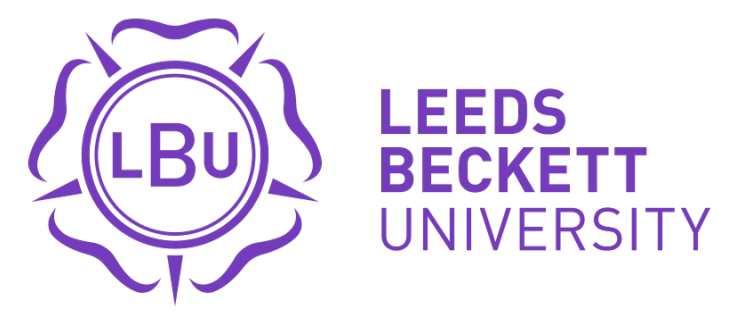

Citation:

Omotayo, T and Olanipekun, A and Obi, L and Boateng, P (2020) A systems thinking approach for incremental reduction of non-physical waste. Built Environment Project and Asset Management. ISSN 2044-124X DOI: https://doi.org/10.1108/BEPAM-10-2019-0100

Link to Leeds Beckett Repository record:

https://eprints.leedsbeckett.ac.uk/id/eprint/6800/

Document Version:

Article (Accepted Version)

The aim of the Leeds Beckett Repository is to provide open access to our research, as required by funder policies and permitted by publishers and copyright law.

The Leeds Beckett repository holds a wide range of publications, each of which has been checked for copyright and the relevant embargo period has been applied by the Research Services team.

We operate on a standard take-down policy. If you are the author or publisher of an output and you would like it removed from the repository, please contact us and we will investigate on a case-by-case basis.

Each thesis in the repository has been cleared where necessary by the author for third party copyright. If you would like a thesis to be removed from the repository or believe there is an issue with copyright, please contact us on openaccess@leedsbeckett.ac.uk and we will investigate on a case-by-case basis. 


\title{
A systems thinking approach for incremental reduction of non-physical waste
}

\begin{abstract}
Purpose: Continual cost reduction of overhead costs of building projects can realign the concept of post-contract cost control towards value driven construction projects and stakeholders satisfaction. This study synthesized and analysed the viable continuous improvement measures critical for waste reduction during the execution phase of a building project.
\end{abstract}

Design/Methodology/approach: A review of existing literature facilitated a list of continuous improvement measures. This literature review findings enabled a Likert scale questionnaire which was administered to two-hundred and fifty (250) small and medium scale construction companies (SMSCC) in Nigeria. Multiple linear regression statistical tests deduced the significant cost reduction measure from which a causal loop diagram was designed to indicate continuous improvement measures during the execution phase of a building project.

Findings: Cogent construction activities associated with overhead costs were deduced from the statistical tests as being payment of suppliers and subcontractors; and purchase orders. An all-inclusive casual loop model for cost reduction through waste minimisation in construction projects as a viable oriented mechanism for meeting clients' requirements was developed.

Practical implications: The causal loop continuous improvement model recognised external and internal factors which are crucial for SMSCC to focus on for their organisational growth and performance enhancement.

Originality or value: A focus on non-physical waste in construction organisations potentially addresses behavioural challenges for continuous improvement.

Keywords: Continuous improvement, Cost control, Cost reduction, Post-contract, Systems thinking

Paper type: Research paper. 


\section{Background of the study}

Construction post-contract cost control should ensure that resources of construction projects are kept within the budget for the timely delivery of construction projects (Potts, 2008). The resources used during construction projects are typically identified within the categories of plant, labour, and materials but also include professional expertise from skilled workers, finance, and information technology (Emuze, Smallwood and Han, 2014; Ameyaw et al., 2015; Amoatey et al., 2015; Asiedu, Frempong and Nani, 2016; Broft, Badi and Pryke, 2016). These resources are dependent on a finite budget. Therefore, the quantity surveyor has the prerogative to manage the available resources using relevant techniques and expertise efficiently. A number of such techniques fall within the remit of post-contract cost control, with the use of cash flow by the contractor to assess cash inflow and expenses and to keep the project within budget (Ashworth and Perera, 2015). Therefore, efficient post-contract cost control can determine the profitability of a contractor. The available finances for construction projects have to be managed effectively for the construction company to gain (profit) without lowering the quality in the process of cost reduction and maintenance (Ozcan-Deniz and Zhu, 2017; Santos, Flintsch and Ferreira, 2017).

Professionally, a quantity surveyor ensures that construction cost is maintained within budget, while allowing an appropriate profit margin for the contractor and delivery of the final product to the client at a reasonable cost. According to Sanni and Durodola (2012), some cost controlling techniques used in Nigeria are monitoring labour, equipment and material cost; overhead monitoring; taking corrective action; identifying cost overruns; analysing cost reports; keeping and using historical data; analysing cost variance, forecasting cost of completion; summarising profit and loss. These are traditional cost control techniques and do not provide necessary cost checks at the operation stage in a project lifecycle (Omotayo and Kulatunga, 2016). Due to increasing complexity of construction projects, new post contract cost control techniques for complex projects are needed (Abobakr, 2018).

Kaizen costing is an effective post-contract cost control technique in construction. Kaizen costing emphasises on continuous improvements, as opposed to phased improvements in the production process to reduce costs (El Dardery, 2017). Kaizen has been identified as effective techniques for construction waste reduction, improved quality of the final product, improved profitability, and competitiveness of a company (Kaur \& Kaur, 2013; Martin, 1993; Smadi, 1993; Omotayo et al., 2019). The use of kaizen in construction can be combined with the 
traditional costing systems for enhanced effectiveness by improving the number of productive working hours (Budugan \& Georgescu, 2009). The study conducted by Budugan \& Georgescu (2009) shows that employee working hours improvement can lower the impact of variable costs and thereby the total production cost. The number of productive hours achieved by employees in a construction company has an influence on the overall cost of a project; therefore, teamwork is vital to the success of a kaizen approach. These key benefits of Kazien have not been widely studied in Nigerian construction industry settings, as the focus has mostly been on items such as target costing and improved estimating techniques for reducing cost overrun and project abandonment (Sanni and Hashim, 2013, Frimpong et al., 2003, Mansfield et al., 1994).

This study analyses the feasible kaizen measures critical for non-physcial waste reduction during the execution phase of a building project. Such knowledge contribution is beneficial to SMMMCs in identifying and implementing waste minimisation and control practices in construction.

\section{Overhead cost and incremental waste reduction}

Nagapan et al. (2012) and Nagapan et al. (2011) opined that waste can be physical and nonphysical. They defined physical wastes as debris from the construction process and can include materials waste in the form of concrete, wood, metals, plastic, tiles, insulations, paints, soil, and stones, ceramics, glass, and bricks. While the non-physical waste is non-value adding activities such as material handling, inventory, process, and delays. Nagapan et al. (2012) classified these wastes as originating from procurement, workers, site conditions, handling, management, and external influencing factors such as waste from packaging; leftovers from construction materials; design error or changes; poor storage; pilfering and handling of materials. The general causes of construction waste include poor allocation of resources; poor record keeping; vandalism, variation and rework; damage as a result of weather or mishandling; damage as a result of transportation; composite and design of building; poor quality material supplied and used on-site, and site office waste (Wahab and Lawal, 2011).

Construction waste is a problem in the Nigerian construction industry, especially material wastes on construction sites (Eze, Seghosime, Eyong, and Loya, 2017; Haruna, Usman, Oraegbune, Muhammad, \& Bamidele, 2017; Ugochukwu, Agugoesi, Mbakwe, and Abazuonu, 2017). On a typical construction site in Nigeria, Ugochukwu et al. (2017) estimated the average percentage of waste from timber, tiles, sandcrete blocks, reinforcement bars and concrete to be $5.5 \%, 3.47 \%, 1.6 \%, 1.58 \%$ and $1.55 \%$ respectively. However, this is quite lower than the 
$11.28 \%$ average waste generation on construction sites in India (Amirthakadeshwaran and Kalpana, 2017). Nevertheless, the effect of these wastes is increased project costs (Haruna et al., 2017) or $4.0 \%$ project cost overruns (Saidu and Shakantu, 2016). The wastes occur mainly from material handling (Ugochukwu et al., 2017) and theft and vandalism on construction sites (Eze et al., 2017). Generation of wastes is also associated with poor construction on sites; for instance, poorly designed formwork leads to enormous concrete wastes (Haruna et al., 2017). There is also very limited reuse of wastes on construction sites (Mudashiru, Oyelakin, Oyeleke, and Bakare, 2016). Furthermore, artisans such as carpenters, masons, iron benders and electricians are mostly responsible for material wastes on construction sites (Haruna et al., 2017).

Mitigating construction wastes enhances the performance of construction projects, especially to prevent cost overruns by about $0.4 \%$ of construction cost (WRAP, 2014). As a result, in the $\mathrm{UK}$, the waste management policy, particularly with regard to materials wastage, is well implemente (Clarke, Williams and \& Turner, 2019). However counterparts in the developing economies such as in Nigeria are yet to adopt and embrace these strategies. On the other hand, strategies for non-physical construction waste miimisation are rare. Kaizen can be employed to reduce both physical and non-physical waste.

Meanwhile, the implementation of lean construction and the derivate (Kaizen) for construction waste reduction in the Nigerian construction industry is very low due to barriers to implementation (See (Aisha \& Kasimu, 2019; Oladiran, 2017; Olatunji, 2008)). The barriers are related to skills and knowledge, management in construction organisations, government support, construction professionals' attitude and resources. (Olatunji, 2008). The knowledge and skills for implementing lean construction are low in the industry (Amade, Ononuju, Obodoh, Okorie, \& Tech, 2019; Sholanke, Chen, Newo, \& Nwabufo, 2019), and more professional training is required (Amade et al., 2019). Also, the commitment and support of top managers and executives in construction companies to lean construction implementation is almost non-existent (Sholanke et al., 2019). There is a general lack of government policy for promoting changes that can influence the application of lean construction in Nigeria. Furthermore, negative attitude to embrace changes is generally dominant in the industry, often exacerbated by silo procurement, sentience, corruption and adversarial relationships (Amade et al., 2019; Sholanke et al., 2019). Finally, there is a shortage of resources such as power 
infrastructure and IT platforms to support lean construction planning and implementation (Amade et al., 2019; Olatunji, 2008). The funding of construction projects is very poor, leaving no room for the implementation of new process techniques like lean construction (Sholanke et al., 2019).

In incremental waste reduction for Kaizen, activities culminating to post-contract cost reduction are mainly overhead cost reduction. Overhead cost is also non-value adding, labour expense that raises the overall cost (Enshassi, Aziz and Karriri, 2008; Lan Oo, Yean Yng Ling, and Soo, 2014; Hetherton and Jennifer, 2015). Examples of non-labour overhead cost are depreciation, the cost of processing payments, administrative charges and costs which are indirectly related to the construction process. Hence, in the context of a Kaizen application in post-contract cost control, the focus will be on overhead cost reduction. This is because overhead cost reduction is usually fixed during a time period. Kaizen is concerned with activities which can be controlled by the stakeholders involved in the construction process. The construction team needs to focus on the supply chain, material handling, equipment hire and preliminary items of work. The Table 1 below shows the different activities carried out by construction operatives which lead to the accumulation of overhead cost.

The activities in Table 1 are related to the general overhead cost which can be reduced through the continuous improvement process (Kaizen costing). Plant and equipment depreciation costs (MSETUP) are usually paid by the contractor during the lifetime of the construction process. By engaging in constant negotiation with the equipment supplying company, the overhead cost >>>Insert Table $1<<<$

relating to depreciation of plant and equipment will be reduced. Handling of equipment (setup) and materials which are supplied as a result of the purchase of building materials (POM) have overheads such as administrative charges relating to payment. Preliminary items of work that are related to fixed payments for water, electricity, first aid, inventory, security and so on, can be reduced by monitoring usage. Hence, incremental reduction of muda (the Japanese term for waste) on construction sites will provide an opportunity with the implementation of Kaizen.

\subsection{Exploring drivers for mobilisation and equipment setup (MESE)}

Construction schedule and program of works has been a major determinant of equipment mobilisation (Leśniak and Juszczyk, 2018). Construction project complexity determined the type of equipment which will be used. In simple housing construction projects, bulldozers, 
concrete mixers, tree pullers and less heavy equipment such as tower cranes will be avoided. Depreciation, fixed cost, storage, and operations cost are monitored with the aid of accounting software (Leśniak and Juszczyk, 2018; Nagata et al., 2018). The aforementioned costs are synonymous to overhead costs. Other overhead costs associated with material and equipment setup are salaries of plant operators and maintenance (Nagata et al., 2018). The mobilisation phase of construction will also incur taxation, construction administrative charges, and travel or delivery expenses.

\subsection{Exploring drivers for drawing reviews (DRR)}

Delays culminating to schedule extensions may arise from drawing reviews. The cost implication of delays may be beyond financial estimation. A contractor may lose a construction project when there are delays in submission or drawing revisions (Nagata et al., 2012). Consequently, an additional administrative charge, payment for overtime, additional salaries may be incurred as construction planning overhead during this phase (Nagata et al., 2012). Communication issues also affect drawing revisions, this depends on the nature of technology deployed. Using building information modelling (BIM) enhance communication and information sharing during drawing reviews (Oduyemi, Okoroh and Fajana, 2017; Rowlinson, 2017). Drawing reviews depends on the procurement and contract route adopted the employer.

\subsection{Exploring drivers for preliminary items of work (PI)}

Preliminary items of work have been discovered to contribute to overhead cost in building construction projects (Vivan et al., 2015; Nagapan et al. 2012; Hafez, 2015). Preliminaries are part of the bill of quantities. Some of the items which contribute to preliminaries are insurance, water supply, electricity, storage, temporary site office, scaffolding, temporary road, security, staff transportation and other miscellaneous items (Entrusty, 2009). Preliminary items of work have been viewed to affect the cost overrun if not priced properly.

2.4 Exploring drivers for construction cost planning, general planning and resource planning (CGPG)

Having an incomprehensive construction cost plan may lead to cost overrun. Design errors, estimating and inadequate cost control coupled with systemic errors in the allocation of resources have been argued to influence the eventual occurrence of an excess of overheads (Oyedele, 2015; Samphaongoen, 2010). Ashworth \& Perera (2015) explicated the factors 
which may affect the pre-contract planning phase as design information, historical data, market conditions, size of the project and the heuristics of professionals involved in the planning phase.

\subsection{Exploring drivers for construction variations (CVMI)}

Construction variations have been categorised as minor or major, depending on the nature, impact, and volume of rework. Variation is an evidence of inadequate cost planning leading to increasing cost of construction. Variations occur when there is poor estimation; inflation; fluctuations in prices of building materials; program planning problems; exchange rate increment; workmanship errors; rework and quality issues; theft; design information misinterpretation; interest rates; corrupt practices on the site and inexperienced skilled and unskilled workers (Omotayo, 2017; Danese et al. 2012). These contributing factors have been studied as represented in geographical locations, time and circumstances of building construction projects.

\subsection{Exploring drivers for plant and equipment depreciation (PEOV)}

Plant and equipment depreciation cost is synonymous to the mobilisation of plant and equipment. Overhead costs emanating from plant and equipment depreciation as prescribed by Araujo et al. 2016; Selviaridis \& Norman 2014; Emuze \& Julian Smallwood 2014, pertains to maintenance, operation, taxation and salaries of the operator. Plant and equipment are tangible fixed assets. A continual reduction of maintenance and operation cost may create improvements in profits. However, cost such as taxation and salaries of operators cannot be reduced.

\subsection{Exploring drivers for purchasing orders and material deliveries (POM)}

Waste arising from material handling and transportation are physical and contribute to overhead costs estimated during cost planning (Omotayo, 2017). This overhead depends on the skilled manpower employed on the construction site; health and safety policies; construction plants and equipment; supply chain system; theft; communication; transportation mechanism and construction methods employed (Lammoglia et al. 2010; Oyewobi et al., 2016). These drivers determine the consistency and volume of overheads incurred.

\subsection{Exploring drivers for paying suppliers and subcontractors (PSL)}

Administrative charges; cost of accounting software; collusion between supplier and subcontractor; corrupt practices; new technology; communication; conflict and disputes; 
quality of workmanship; quality of material delivered, are the drivers of payment to suppliers and subcontractors (Granja et al., 2005; Nagapan et al. 2011; Nagapan et al. 2012). The abovementioned drivers deliver are intricate factors capable of posing cost and time overrun circumstances. A focus on these factors potential reduces overhead costs associated with paying suppliers and subcontractors.

$>>>$ Insert Figure $1<<<$

Figure 1. Summary of drivers for continuous improvement

\section{The workings of incremental cost reduction}

Shang and Pheng (2013) explained that Kaizen could be separated into maintenance and improvement. Maintenance is related to keeping the cost within budget, while improvement identifies gaps which allow for the additional reduction of cost. The maintenance aspect involves a management function which would be narrowed down further to a policy guiding waste reduction in the office, rules and regulations, guidelines and procedures for an employeeemployer relationship, and elimination of waste. This managerial function is essential to be represented as a culture within the organisation before the commencement of site activities. Reduction of waste which is also known as Muda in Japanese involves all non-value adding activities (IFS, 2010). Therefore managing value during production is essential to the realisation of waste reduction during production, the achievement of which is dependent on data / information such as the work breakdown structure and cost estimates.

Cost estimates must be established in a standardised framework. A repetitive process of reducing waste in organisations and on construction sites can proactively eliminate waste before it occurs (Omotayo and Kulatunga, 2015). The plan-do-check-act (PDCA) process, for example, can be implemented from inception to completion of construction projects.

$>>>$ Insert Figure $2<<<$

$>>>$ Insert Figure $3<<<$

The PDCA process is the bedrock of continuous improvement (Omotayo and Kulatunga, 2017). In Figure 2, the PDCA process begins with a section area identification of waste generating activities such as material handling during construction. Implementation of this process has a concomitant relationship with the refining of construction workers' response(s) towards change. The kaizen team is also a change management team. Therefore, the process of 
implementing this type of change deals with the monitoring, conforming and controlling of practical approaches to minimising waste on construction sites.

The process of incrementally reducing cost during construction for SMSCC depends on activities which are not actually adding value. Non-value- added activities in construction are the gaps which can be noted in Figure 1. They are categorised as material delivery (transportation and handling); overhead cost reduction during construction; preliminary cost reduction; supply; variation management; plant and equipment hire (depreciation), and payment of sub-contractors (Yates, 2013; Jayamathan and Rameezdeen, 2014; Khanh and Kim, 2015; Yahya, Boussabaine and Alzaed, 2016). The waste category in this study can comprise both physical and non-physical wastes (Sandhu, 2014; Ajayi et al., 2016; Chatziaras, Psomopoulos and Themelis, 2016; Yahya, Boussabaine and Alzaed, 2016). For instance, waste arising from material handling and transportation are physical, but waste arising from overheads are non-physical. Preliminary items such as the overhead costs of electricity, water, stationery, road, security and so on are also major gaps which can be closed for the reduction of cost. Overhead costs relating to preliminaries, payment of contractors (administrative charges), suppliers, equipment and variation management can be minimised throughout the course of the construction project.

\section{Methodology}

This research was carried out in three stages, the first stage involved a review of existing literature to identify the critical activities leading to increment in wastage during construction. In the second phase, questionnaires were administered to the respondents based on the findings in literature documented in table 1. The Likert scale structure of survey data collection had five (5) points for the respondents' consideration. These are strongly disagreed; disagree; Neutral; agree; strongly agree from one (1) to five (5) respectively. The questionnaire was used to gather relevant information from an SMSCC in Nigeria with respect to the topic investigated.

\subsection{Sampling}

Drawing from Erickson and Nosanchuk (2002) formula for sample size determination, a sample frame of 250 companies was identified of which Eighty-four (84) companies were contacted and One hundred and thirty-five (135) questionnaire were returned and analysed. This provided an average of 1.6 questionnaires which were returned per SMSCC. Furthermore, Sanni and Durodola (2010) noted that there are over a thousand SMSCC in Lagos, Nigeria. 
During the distribution of the samples, Lagos, was chosen as part of the research scope because the state provides a quarter of the gross domestic product (GDP) of Nigeria (Issa et al., 2013 \& Dantata, 2008).

Erickson and Nosanchuk (2002) observed that sample size depends on the number of subjects the research intends to look at. The author also proposed the formula for sample size as:

$$
\mathrm{SE} \underset{\sqrt{N}}{\underline{\square}}=\frac{\square}{\sqrt{1000}} \quad=\underline{\square}
$$

The standard error is "SE" and a represents the standard deviation. Therefore, the square root of the total number is the sample size. However, in order to analyse more details from a large data sample. The sample size of eighty-four (84) is higher than the calculated value 32 from the SE.

The respondents were mainly construction project managers and quantity suvrveyors. This group of respondents were selected based on the premise of purposive sampling technique where experience level and the right expertise is the main focus.

Multiple linear regression was adopted to predict the plausible variables for the casual loop diagram (Field, 2005; Pallant, 2016). The multiple linear regression analysis was used to predict the activities which are definitely contributing waste in expenditure and associated costs. A focus on these wastes generating activities provides a basis for the model development. The model development phase depends on factors with the highest Beta Values and significance values higher than or equal to 0.05 .

\subsection{Summary of respondents and samples}

Seventy-seven (77) quantity surveyor and fifty-eight (58) project managers responded to the questionnaire, with an uneven distribution from the eithty-four (84) SMSCC. The detailed analysis of the sample's experience within the organisation have been provided in the graph below.

$>>$ Insert Figure $4<<$ 
Over $60 \%$ of the sample population have up to fifteen (15) years experience in the construction industry. Furthermore, the scale of the sample population in terms of the number of staff they hold were reviewed. Over $58 \%$ of the sample zie have over one hundred (100) employees. This indicated that majority of the samples collected were from medium scale construction companies.

$>>>$ Insert Figure $5<<<$

\section{Data analysis}

The data analysis started with correlation of all the extracted variables from table 1 and ended with a regression analysis.

\subsection{Spearman correlation}

The spearman's Rho correlation for the variables as presented in table 2 below, indicates significant variables in red. The variables with asymptotic significant values ( $p$-values) which are less than 0.05 have been coded in red and taken forward into the multiple regression analysis. These variables are PEOVER, CVMINI, POM, PSL, CPGP and PI. These variables were selected because they have $\mathrm{P}>0.05$ even though the relationship between the variables are very weak.

$>>$ Insert Table $2<<$

\subsection{Multiples linear regression}

Converting data into useful information for impact assessment requires further analytical procedures and interpretations. The purposes of the multiple linear regression was to evaluate the impact and not causality, expunge weaker variables for the framework development, and tie a relevant interpretation to figures.

The multiple linear regression analysis looked at the correlation pairs and analysed the predictors based on how they are affected by the dependent variable. The model for the multiple linear regression was aimed at displaying the predictive power of the independent variables on the dependent variables. POM was considered to be a dependent variable because of the overheads involved in the purchase of materials and delivery and the nature of its occurrence. Furthermore, Ala- Risku and Karkkainen (2004) and Omotayo and Kulatunga (2017) confirmed that overhead cost related to material delivery have a massive impact on overall construction cost. 
$>>>$ Insert Table $3<<<$

The predictors are PEOV, CVMI, PSL, CPGP and PI. In reference to table 2, these aforementioned four predictors displayed significant values above 0.05 twice and tangible correlations within variable set. The linear regression analysis further justifies their inclusion. The $\mathrm{R}$ square value of 0.070 signifies a $7 \%$ variance of the predictors in overhead cost relating to purchasing orders and material deliveries (POM). Although the R squared is very low, the model significance in table 4 , indicates a significace of $\mathrm{P}<0.013$. Hence, the model is significant for this analysis.

$>>>$ Insert Table $4<<<$

The $F$ value of 3.032 and a p-value $<0.013$ indicates a significance on the model. The significant contributory change to the dependent variable from the standardised Beta for POM is PSL with a value of $0.217 \mathrm{p}$-values $<0.050$ at 0.007 . PE overheads have a Beta effect on the dependent variable with a value of 0.121 . However, this is not significant.

\section{$>>$ Insert Table $5<<<$}

The findings of the linear regression analysis confirmed that overhead costs related to paying subcontractors, labourers and suppliers have a comprehensive impact on overhead costs associated with purchasing orders and material delivery. Hence, the key findings identified subcontractors and supplier payments, purchasing and delivering building materials as the key components of those overheads which continuous improvement can focus on. Some of these overheads are fixed costs, of which some are percentages and charges which can be reduced incrementally.

\section{Model development: Systems thinking}

The choices and changes made in an organisation always be impacted by existing internal and external factors (Castelle and Jaradat, 2016; Gates, 2016; Aven, 2018; Domenech, Eveleigh and Tanju, 2018). Systems thinking accentuates the causes and effects of decisions (Király, Köves and Balázs, 2017; Grohs et al., 2018). Hence, change management in an organisation can benefit from understanding matching variables to comprehend scenarios. Senge (1990) as cited by (Akhtar et al., 2018) opined that systems thinking is the fifth discipline of a learning 
organisation. Applications of systems thinking in organisational culture studies prove the existence of unforeseen phenomenon in every unilateral decision (Király, Köves and Balázs, 2017; Grohs et al., 2018; Molderez and Ceulemans, 2018). In the attainment of effectiveness in organisations, systems thinking inclines towards cohesive change management and continual mitigation of effects as end games for causes.

In continuous improvement studies, systems thinking can clearly delineate the causes and effects in a loop diagram. Thereby showing the relationships between sub-factors influencing the major factors leading to continuous improvement. Vensim PLE 7.2 software for systems thinking was used to create a direct relationship between the outcomes of the regression analysis.

$>>>$ Insert Figure $6<<<$

A causal loop continuous improvement model was designed for SMSCC. The model expunged latent variables which are outside the statistical phenomenon. For a detailed analytical perspective for this study, a causal loop diagram was developed for POM and PSL causal variables. The causal variables have determinants in the form of sub-causal variables. The dynamic complexities for continuous improvement implementation in the construction industry primarily depend on cost control, people management skills and the supply chain system. The POM and PSL causal variables are thus presented as a hierarchical chart. The chart in figure 7, displays the two criteria representing the causal variations and sub-criteria for sub-variables for incremental cost reduction. These sub-criteria were elucidated from the literature review sections.

\section{$>>>$ Insert Figure $7<<<$}

The internal and external influences on overhead costs have been listed under the sub-criteria. In figure 5, the external factors which are not under the control of the cost consultant and stakeholders are distinguished for the purposes of systems thinking.

\section{$>>$ Insert Figure $8<<<$}

The external and internal relationships for the variables were considered in analysing the causes and effects of overhead costs and continuous incremental reduction. The systems thinking causal loop diagram in Figure 6 created relationships and additional variables for this study as illustrated. 


\section{Implications of findings for non-physical waste reduction}

Causal loop diagrams in Figure 7 has arrows, + and - signs. The arrows indicate the relationship between the variables, while the + and - signs expressed the effect of one variable on another. In designing the causal loop diagrams, the positive relationship between variables drives the thought process of the designer. For instance, POM and PSL lead to more overhead costs in construction. There are Nine (9) reinforcing loops were generated from the causal loop diagram in Figure 6. The first reinforcing loop R1 created a relationship between PSL and communication via relationship and teamwork. The existence of relationship and teamwork strengthens effective communication and this proper payment of supplier and subcontractors. Relationship and teamwork were added to the sub-variables as part of the systems thinking model after thorough analysis by the researcher. R2 has a positive reinforcing loop between accounting software cost and PSL. Effective communication will lead to improvements in the quality of materials delivered and this promotes better relationship and teamwork during construction as evident in R3.

$>>>$ Insert Figure $9<<<$

R4 has a negative reinforcing loop between collusion between contractors and suppliers, and the quality of materials delivered. If there is a collision, the quality of materials delivered will be lower and thus, a vicious cycle. R5, an increase in purchase orders and material deliveries will also add to the transportation cost and vice versa. R6, associated a reinforcing loop between the supply chain system and POM. When purchase orders and material deliveries increase, the supply chain system will boom. Construction method applied for a project depends on the management strategy and health and safety policies. Between construction methods and health and safety policies, there is a positive reinforcing loop. Health and safety policies will lead to the type of scaffolding, construction hours and approach to the construction project. The construction method also influences, the security provided on the construction site positively.

R8 revealed new variables which are meant to enhance the causes and effects of corrupt practices on the payment of suppliers. In R1, management strategy was discovered to have a massive influence on managing grievances. For a causality of dispute, there has to be some form of grievance amongst the stakeholders. The effect of grievance during construction is conflict and dispute resolution by the management. Initially, conflict and dispute resolution 
were combined. During the causal loop diagram construction, the researcher discovered a disjointed variable led to the decomposition of conflict and dispute resolution. R9 connects expertise and communication. When there is excellent communication, expertise is improved. Effective application of expertise also promotes good communication during the construction process.

Management strategy was discovered to have a massive influence on a number of variables such as health and safety policies; construction method; plants and equipment; transportation cost; grievances and dispute resolution. In general management strategy reduces overhead costs during construction cost control. The purpose of this system thinking causal loop diagram is to make decisions leading to the reduction in overhead costs. Hence, the variables and subvariables associated with the reduction of construction overhead costs are thus, identified as management strategy; relationship and teamwork; corrupt practices; communication; expertise, transportation cost, quality of materials delivered; construction method; collusion; interest rates and inflation. The selection of these variables is based on their existence in the reinforcing loop and externality.

The sub-variable listed in table 5 are all very important when considering factors associated with waste reduction. Construction waste may be tangible or intangible, whichever the nature of the waste, the causal loop diagram and the factors in table 5 all indicate a strategic approach towards minimising construction waste. A management strategy is very essential for every waste management policy. Once a waste management strategy is in place, communication, corrupt practices; relationship and teamwork; quality of materials delivered and construction methods can be controlled. Other external factors such as inflation and interest rates are very difficult to manage within a project. Notwithstanding, the early identification of external factors which may derail the project objectives can easily be mitigated.

\section{Conclusion and implication for further studies}

The aim of this study was to identify measures for gradual reduction of non-physical waste in construction activities managed by SMSCC. Nigeria was selected as the data source location because of her nature as a developing economy with large number of SMSCCs. The findings identified management strategy enahcnement as a core area within SMSCCs. An incremental improvement in the management strategy of SMSCCs will lead to an overaching improvement in the reduction of nonphysical waste. Furthermore the continual reduction of overheads costs 
resulting from the activity of suppliers, subcontractors, and labourers will definitely create more profit and value for the contractor and project. In most cases, it is very difficult to monitor the activities of the suppliers because of certain forces in the Nigerian construction industry. This type of influential factor includes conspiracy with a project team member to inflate the prices of the construction materials, kickback and other vices on construction sites. Inflation and market forces also have external effects on supplier's and subcontractors' charges.

Incremental reduction of activities related to purchasing orders and material deliveries was identified as the second critical activity. The Kaizen team can focus on this aspect to ensure that the wastage arising transportation of material to site and purchase orders are kept within an allowable cost limit. The cost limits allowed can have a profit and overhead of twenty-five percent plus $(25 \%+)$. In some construction companies, it is a management function. However, focusing on actions relating to purchase orders and material deliveries will definitely assist the contractor in getting more value for money and client satisfaction. Most contractors view construction projects as opportunities to claim for funds arising from all forms of variation. Therefore, some contractors may expect more variation during the course of the project timeline.

Further studies into the systems dynamics of physical and non-physical waste reduction can enhance construction industry productivity and the spur economic growth of developing nations.

\section{REFERENCES}

Ajayi, S. O., Oyedele, L. O., Kadiri, L. O., Akinade, O. O., Bilal, M., Owolabi, H. A. and Alaka, H. A. (2016), "Competency-based measures for designing out construction waste: task and contextual attributes", Engineering, Construction and Architectural Management, Vol. 23 No. 4, pp. 464-490.

Akhtar, C. S., Awan, S. H., Naveed, S., and Ismail, K. (2018), "A comparative study of the application of systems thinking in achieving organizational effectiveness in Malaysian and Pakistani banks", International Business Review, Vol 27 No.4, pp. 767-776

Ameyaw, E. E., Chan, A. P., Owusu-Manu, D. G. and Coleman, E. (2015), "A fuzzy model for evaluating risk impacts on variability between contract sum and final account in government-funded construction projects", Journal of Facilities Management, Vol. 13 No. 1, pp. 45-69. 
Amoatey, C. T., Ameyaw, Y. A, Adaku, E. and Famiyeh, S. (2015), "Analysing delay causes and effects in Ghanaian state housing construction projects", International Journal of Managing Projects in Business, Vol. 8 No. 1, pp. 198-214.

Araujo, L., Gadde, L.E. and Dubois, A. (2016), "Purchasing and supply management and the role of supplier interfaces", IMP Journal, Vol. 10 No. 1, pp. 2-24.

Asiedu, R. O., Frempong, N. K. and Nani, G. (2016) "Parametric time overrun estimation of building projects", Journal of Financial Management of Property and Construction, Vol. 21 No. 3, p. null.

Aven, T. (2018), ,'How the integration of System 1-System 2 thinking and recent risk perspectives can improve risk assessment and management", Reliability Engineering \& System Safety, Vol. 180 No. 1, pp. 237-244.

Bhat, S., Gijo, E. V. and Jnanesh, N. A. (2016), "Productivity and performance improvement in the medical records department of a hospital: An application of Lean Six Sigma", International Journal of Productivity and Performance Management, Vol. 65 No. 1, pp. 98125.

Broft, R., Badi, S. M. and Pryke, S. (2016), "Towards supply chain maturity in construction", Built Environment Project and Asset Management, Vol. 6 No. 2, pp. 187-204.

Castelle, K. M. and Jaradat, R. M. (2016), "Development of an Instrument to Assess Capacity for Systems Thinking”, Procedia Computer Science, Vol. 95 No.1, pp. 80-86.

Chatziaras, N., Psomopoulos, C. S. and Themelis, N. J. (2016), "Use of waste derived fuels in cement industry: a review", Management of Environmental Quality: An International Journal, Vol. 27 No. 2, pp. 178-193.

Chay, T. Xu, Y., Tiwari, A. and Chay, F. (2015), "Towards lean transformation: the analysis of lean implementation frameworks", Journal of Manufacturing Technology Management, Vol. 26 No. 7, pp. 1031-1052.

Cruz, I., Major, M. and Scapens, R. W. (2009), "Institutionalization and practice variation in the management control of a global/local setting", Accounting, Auditing \& Accountability Journal, Vol. 22 No. 1, pp. 91-117.

Danese, P., Romano, P. and Bortolotti, T. (2012), "JIT production, JIT supply and performance: investigating the moderating effects", Industrial Management \& Data Systems, Vol. 112 No. 3, pp. 441-465.

Domenech, J., Eveleigh, T. and Tanju, B. (2018), "Marine Hydrokinetic (MHK) systems: Using systems thinking in resource characterization and estimating costs for the practical harvest of electricity from tidal currents", Renewable and Sustainable Energy Reviews, Vol. 81 No. 1, pp. 723-730.

Emuze, F. and Julian Smallwood, J. (2014), "Collaborative working in South African construction: contractors' perspectives", Journal of Engineering, Design and Technology, Vol. 12 No. 3, pp. 294-306. 
Emuze, F., Smallwood, J. and Han, S. (2014), "Factors contributing to non-value adding activities in South African construction", Journal of Engineering, Design and Technology, Vol. 12 No. 2, pp. 223-243.

Enshassi, A., Aziz, A. A. and Karriri, A. (2008), "Investigating the overhead costs in construction projects in Palestine", Journal of Financial Management of Property and Construction, Vol. 13 No. 1, pp. 35-47.

Fouquet, J. M. (2007), "Design for Six Sigma and Lean Product Development: Differences, Similarities and Links", Asian Journal on Quality, Vol. 8 No. 3, pp. 23-34.

JIL (2016), Lagos City Report. Lagos.

Gates, E. F. (2016), "Making sense of the emerging conversation in evaluation about systems thinking and complexity science", Evaluation and Program Planning, Vol. 59 Vol. 1, pp. 6273.

Grohs, J. R. Kirk, G. R. Soledad, M. M and Knight, D. B. (2018), ”Assessing systems thinking: A tool to measure complex reasoning through ill-structured problems", Thinking Skills and Creativity, Vol.28 No. 1, pp. 110-130.

Hetherton, T. and Jennifer, C. (2015), "When statutes collide: potential recovery of own party adjudication costs", International Journal of Law in the Built Environment, Vol. 7 No. 3, pp. 214-230.

Higgins, J. (2005), "Introduction to Multiple regression". Chapter 4, Excerpted from The Radical Statistician, Available at: http://www.biddle.com/documents/bcg_comp_chapter4.pdf (Accessed 2 September 2018)

Jayamathan, J. and Rameezdeen, R. (2014), "Influence of labour arrangement on construction material waste generation", Structural Survey, Vol. 32 No. 2, pp. 76-88.

Jensen, P. A., and Jóhannesson, E. I. (2013), "Building information modelling in Denmark and Iceland", Engineering, Construction and Architectural Management, Vol. 20 No. 1, pp. 99-110.

Khanh, H. D. and Kim, S. Y. (2015), "Development of waste occurrence level indicator in Vietnam construction industry", Engineering, Construction and Architectural Management, Vol. 22 No. 6, pp. 715-731.

Kim, S. K. (2015), "Lean initiative practice for supplier developments in Philippines", International Journal of Lean Six Sigma, Vol. 6 No. 4, pp. 349-368.

Király, G., Köves, A. and Balázs, B. (2017), "Contradictions between political leadership and systems thinking”, Journal of Cleaner Production, Vol. 140 No. 1, pp. 134-143.

Lammoglia, N. L. Olaya, C., Villalobos, J., Calderón, J., Valdivia. J. and Zarama, R. (2010), "Heuristic-based management (I): variation", Kybernetes, Vol. 39 No. 9/10, pp. 1513-1528. 
Lan Oo, B., Yean Yng Ling, F. and Soo, A. (2014), "Information feedback and bidders' competitiveness in construction bidding", Engineering, Construction and Architectural Management, Vol. 21 No. 5, pp. 571-585.

Leśniak, A. and Juszczyk, M. (2018), "Prediction of site overhead costs with the use of artificial neural network based model", Archives of Civil and Mechanical Engineering, Vol. 18 No. 3, pp. 973-982.

Mohamed H. S. (2015), "Optimal Techniques for Cost Reduction and Control in Construction Sites", Journal of Human Resource Management, Vol. 3 No. 3, pp. 17.

Molderez, I. and Ceulemans, K. (2018), "The power of art to foster systems thinking, one of the key competencies of education for sustainable development", Journal of Cleaner Production, Vol. 186 No.1, pp. 758-770.

Nagapan, S., Rahman, I. A. and Asmi, A. (2011), "A Review of Construction Waste Cause Factors", Asian Conference on Real Estate: Sustainable Growth Managing Challenges (ACRE), (February), pp. 967-987.

Nagapan, S., Rahman, I. A. and Asmi, A. (2012), "Factors Contributing to Physical and NonPhysical Waste Generation in Construction Industry", International Journal of Advances in Applied Sciences (IJAAS), Vol. 1 No. 1, pp. 1-10. 18.

Oduyemi, O., Okoroh, M. I. and Fajana, O. S. (2017), "The application and barriers of BIM in sustainable building design", Journal of Facilities Management, Vol 15 No. 1, pp. 15-34.

Omotayo T and Kulatunga U. (2017), “A Continuous improvement framework using IDEF0 for post-contract cost control". Journal of construction project management and innovation. Vol. 7 No. 1, pp. 1807-1823.

Omotayo, T., Boateng, P., Osobajo, O., Oke, A. and Obi, L. (2019), "Systems thinking and CMM for continuous improvement in the construction industry", International Journal of Productivity and Performance Management, Vol. ahead-of-print No. ahead-of-print.

Oteri, A. and Ayeni, R. A. (2016), "The Lagos Megacity”. Water, Megacities and Global Change, Lagos, Nigeria.

Oyewobi, L. O. Jimoh, R., Ganiyu, B. and Shittu, A. (2016), "Analysis of causes and impact of variation order on educational building projects", Journal of Facilities Management, Vol. 14 No. 2, pp. 139-164.

Ozcan-Deniz, G. and Zhu, Y. (2017), "Multi-objective optimization of greenhouse gas emissions in highway construction projects", Sustainable Cities and Society, Vol. 28 No 1. pp. 162-171.

Rowlinson, S. (2017), "Building information modelling, integrated project delivery and all that", Construction Innovation, Vol. 17 No. 1, pp. 45-49.

Sandhu, K. (2014), "Historical trajectory of waste management; an analysis using the health belief model", Management of Environmental Quality: An International Journal, Vol. 25 No. 5, pp. 615-630. 
Santos, J., Flintsch, G. and Ferreira, A. (2017), "Environmental and economic assessment of pavement construction and management practices for enhancing pavement sustainability", Resources, Conservation and Recycling, Vol. 116 No. 18, pp. 15-31.

Selviaridis, K. and Norrman, A. (2014), "Performance-based contracting in service supply chains: a service provider risk perspective", Supply Chain Management: An International Journal, Vol 19 No. 2, pp. 153-172.

Sharma, S. and Shah, B. (2016), "Towards lean warehouse: transformation and assessment using RTD and ANP", International Journal of Productivity and Performance Management, Vol. 65 No. 4, pp. 571-599.

Stålberg, L. and Fundin, A. (2016), "Exploring a holistic perspective on production system improvement", International Journal of Quality \& Reliability Management, Vol. 33 No. 2, pp. 267-283.

Sholanke, A. B., Chen, S. J., Newo, A. A., \& Nwabufo, C. B. (2019). Prospects and Challenges of Lean Construction Practice In The Building Industry In Nigeria: Architects' Perspective. International Journal of Innovative Technology and Exploring Engineering, 8(8), 667-673.

Suárez-Barraza, M. F. and Ramis-Pujol, J. (2012), "An exploratory study of 5S: a multiple case study of multinational organizations in Mexico", Asian Journal on Quality, Vol 13 No. 1, pp. 77-99.

Vivan, A.L., Ortiz, F.A. and Paliari, J. (2015), "Model for kaizen project development for the construction industry", Gest. Prod.

Yahya, K., Boussabaine, H. and Alzaed, A. N. (2016), "Using life cycle assessment for estimating environmental impacts and eco-costs from the metal waste in the construction industry", Management of Environmental Quality: An International Journal, Vol. 27 No. 2, pp. 227-244.

Yates, J. K. (2013), "Sustainable methods for waste minimisation in construction", Construction Innovation, Vol. 13 No. 3, pp. 281-301. 
Figures

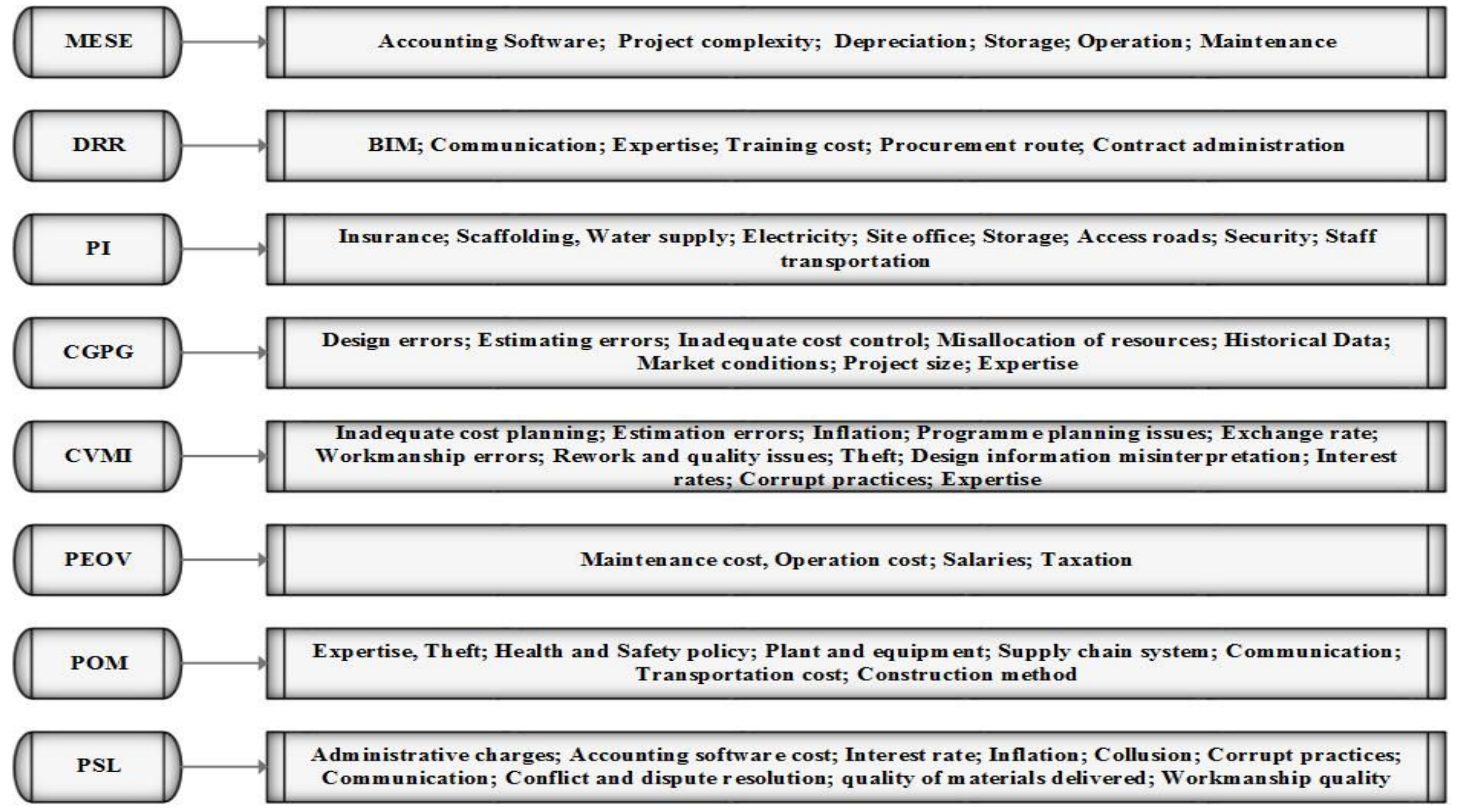

Figure 1. Summary of drivers for continuous improvement factors. 


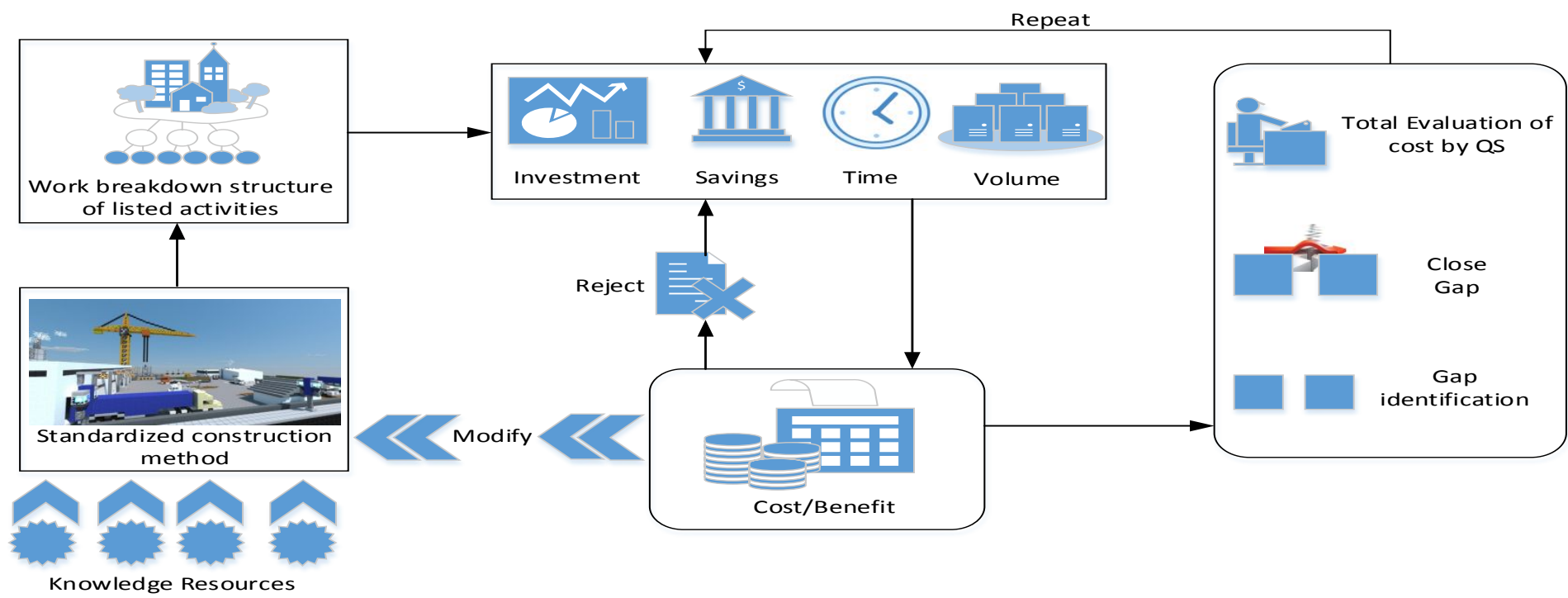

Figure 2. Kaizen costing process during construction (Omotayo and Kulatunga, 2015) 


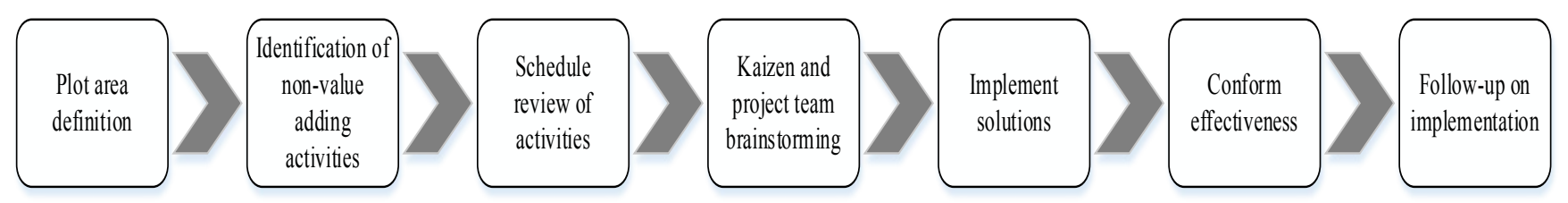

Figure 3. Plan-do-check-act process

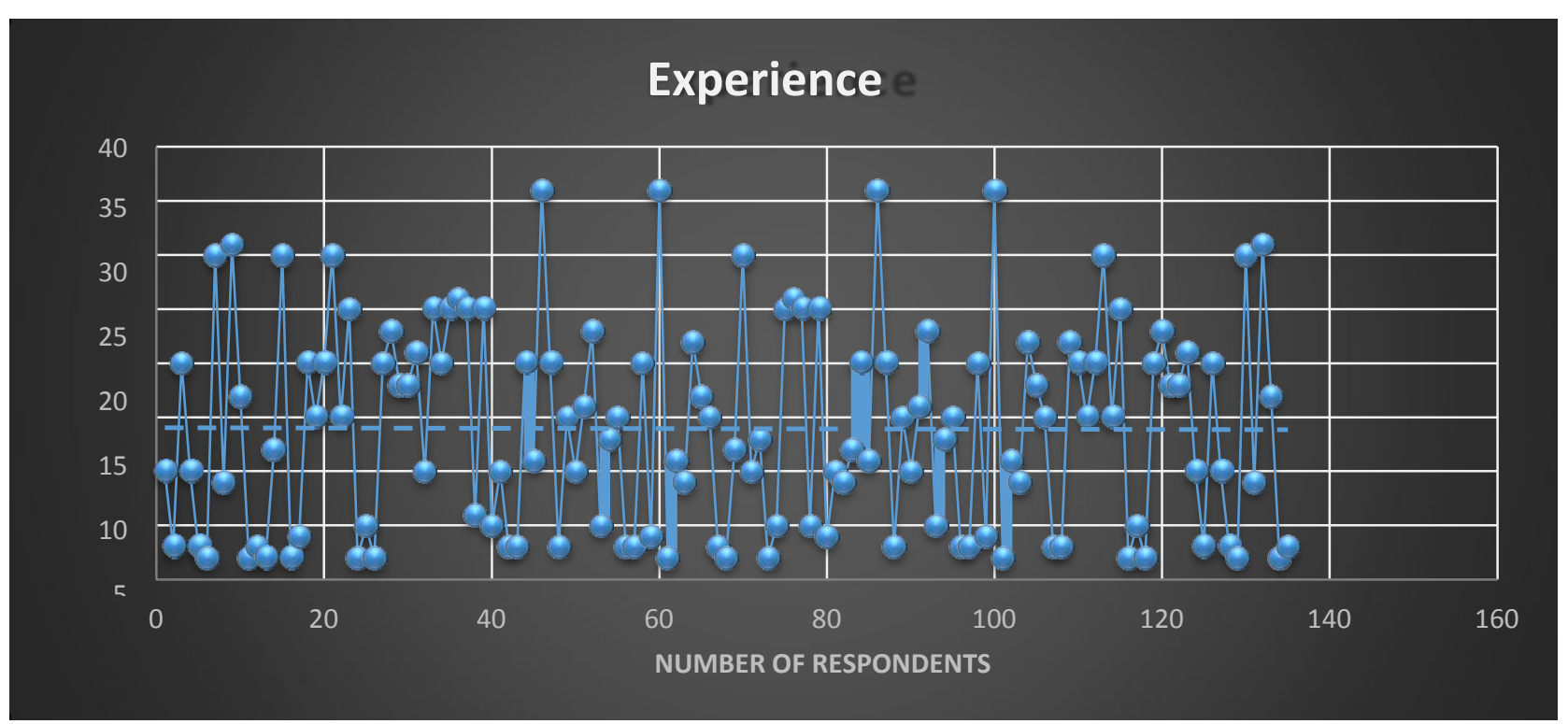

Figure 4: Experience level of the respondents 


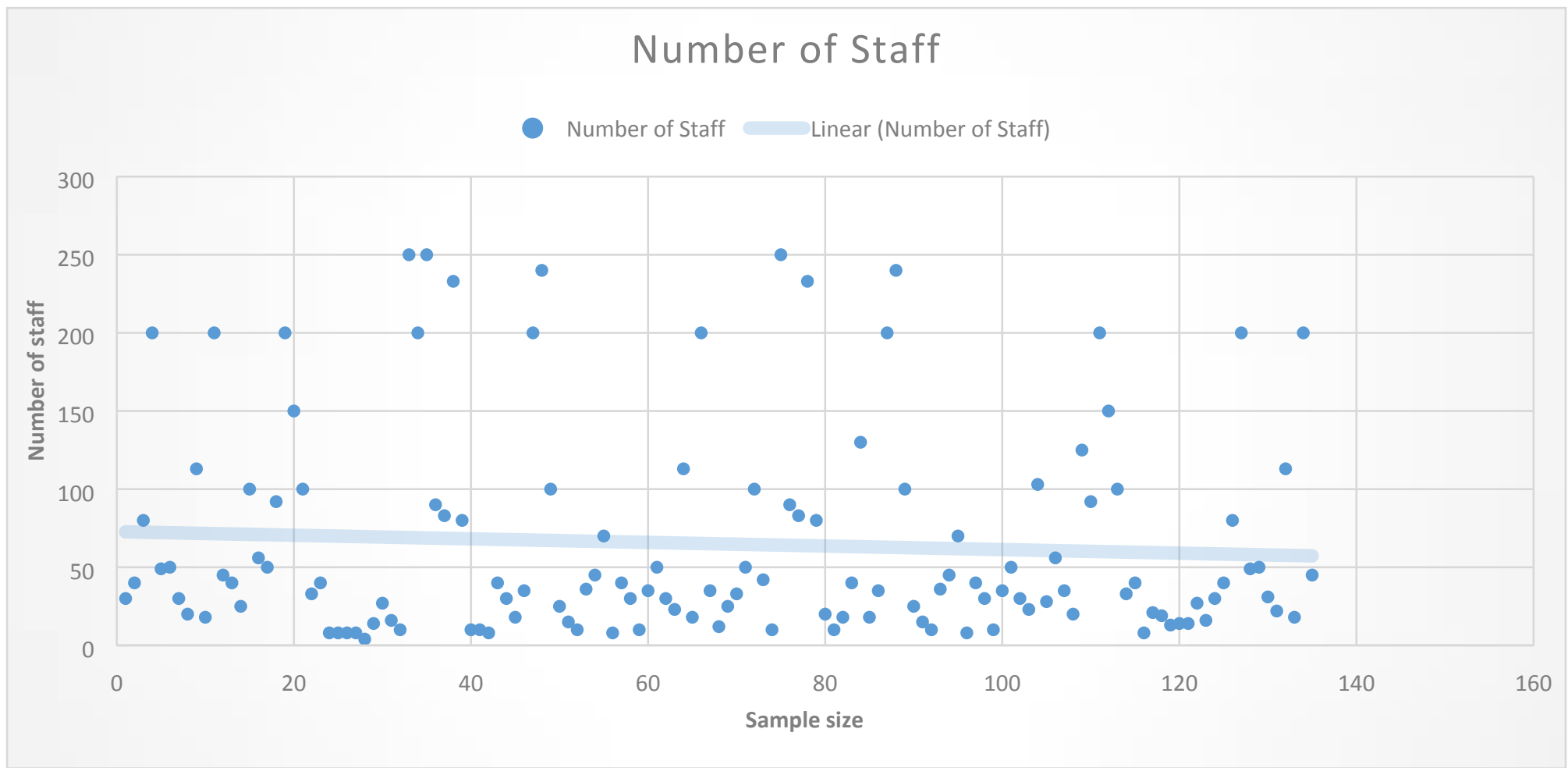

Figure 5: The scale of the sample organisations 


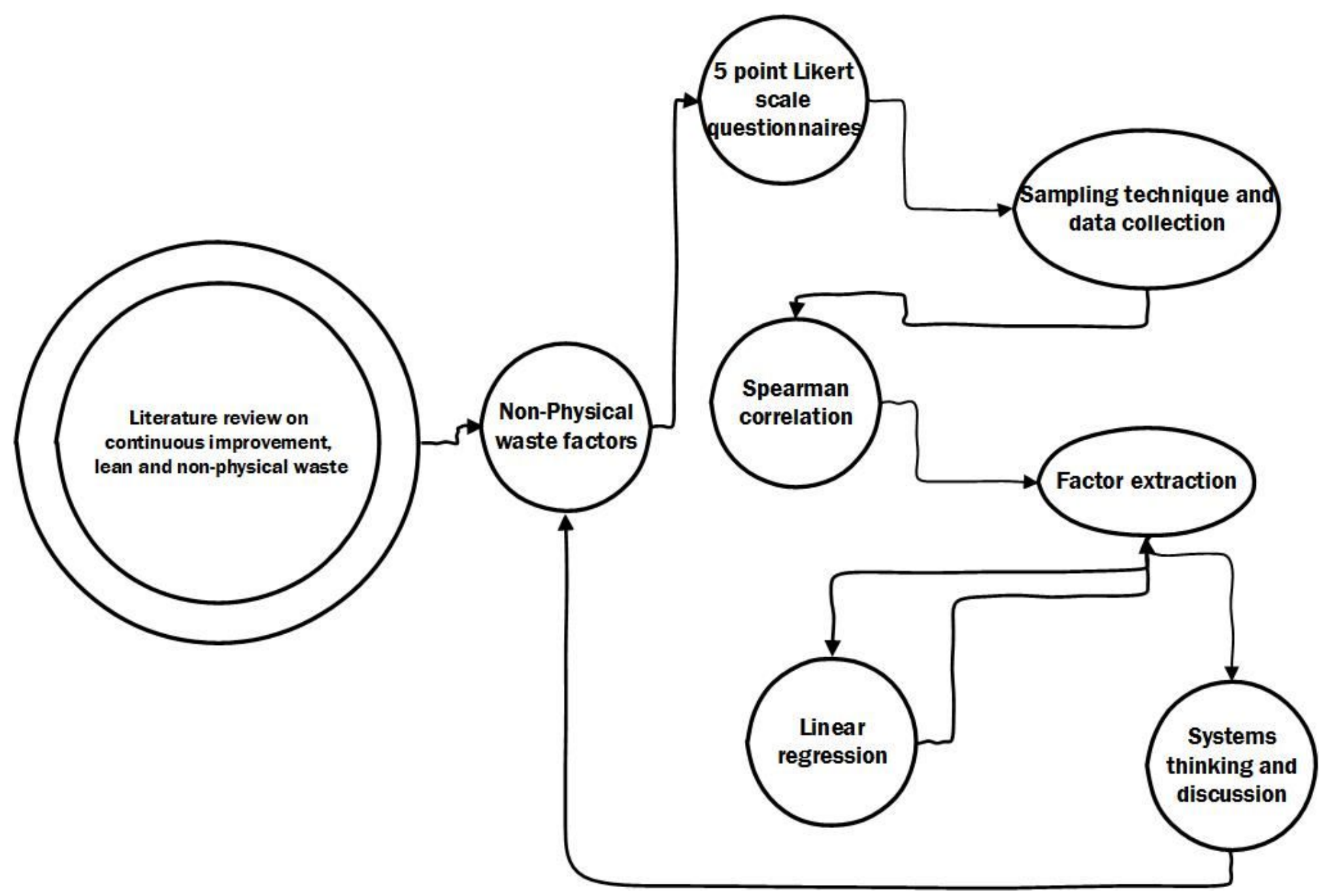

Figure 6. A research framework for continuous improvement. 


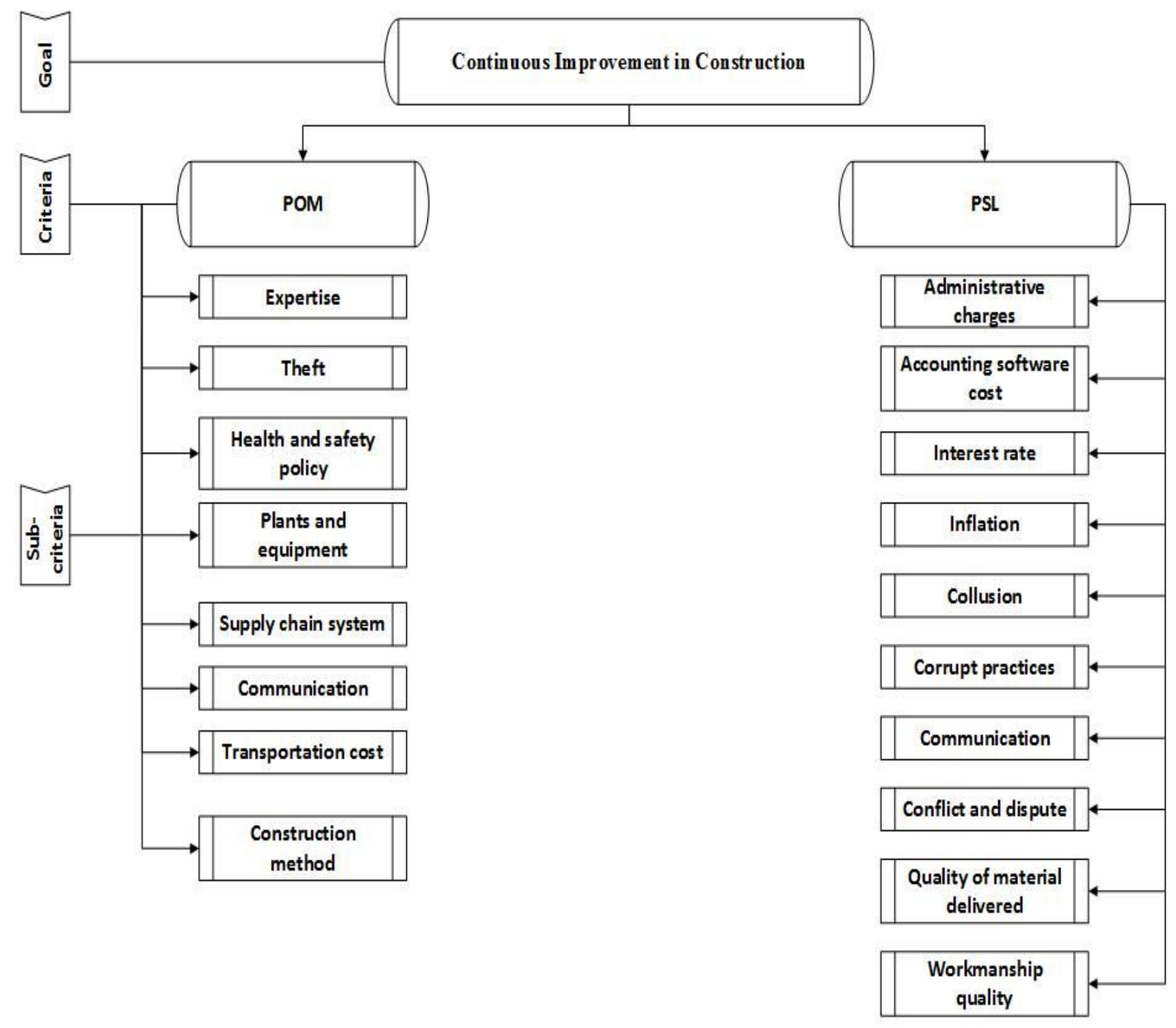

Figure 7. Hierarchy of causal variable for systems thinking loop diagram 


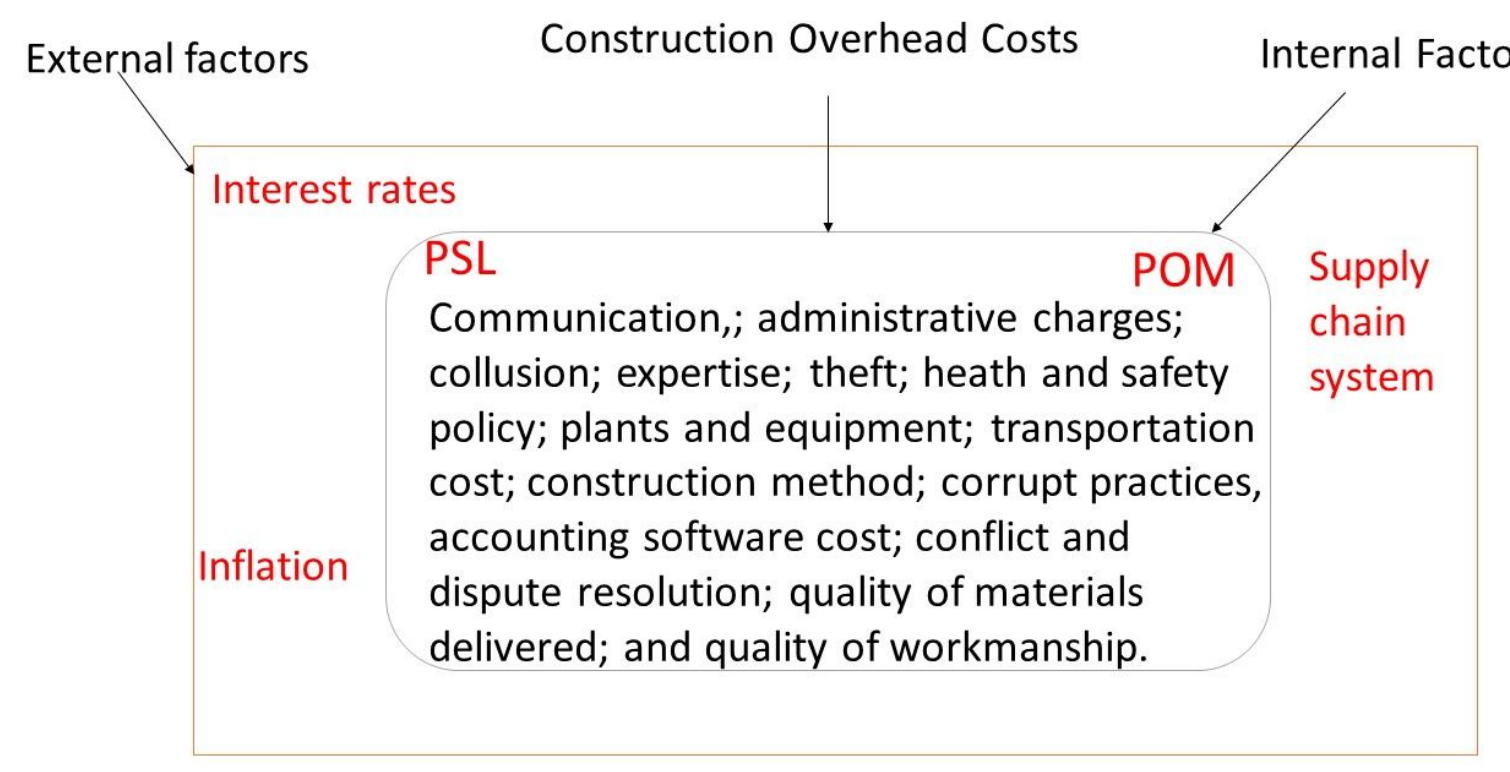

Figure 8. External and internal relationships of the variables. 


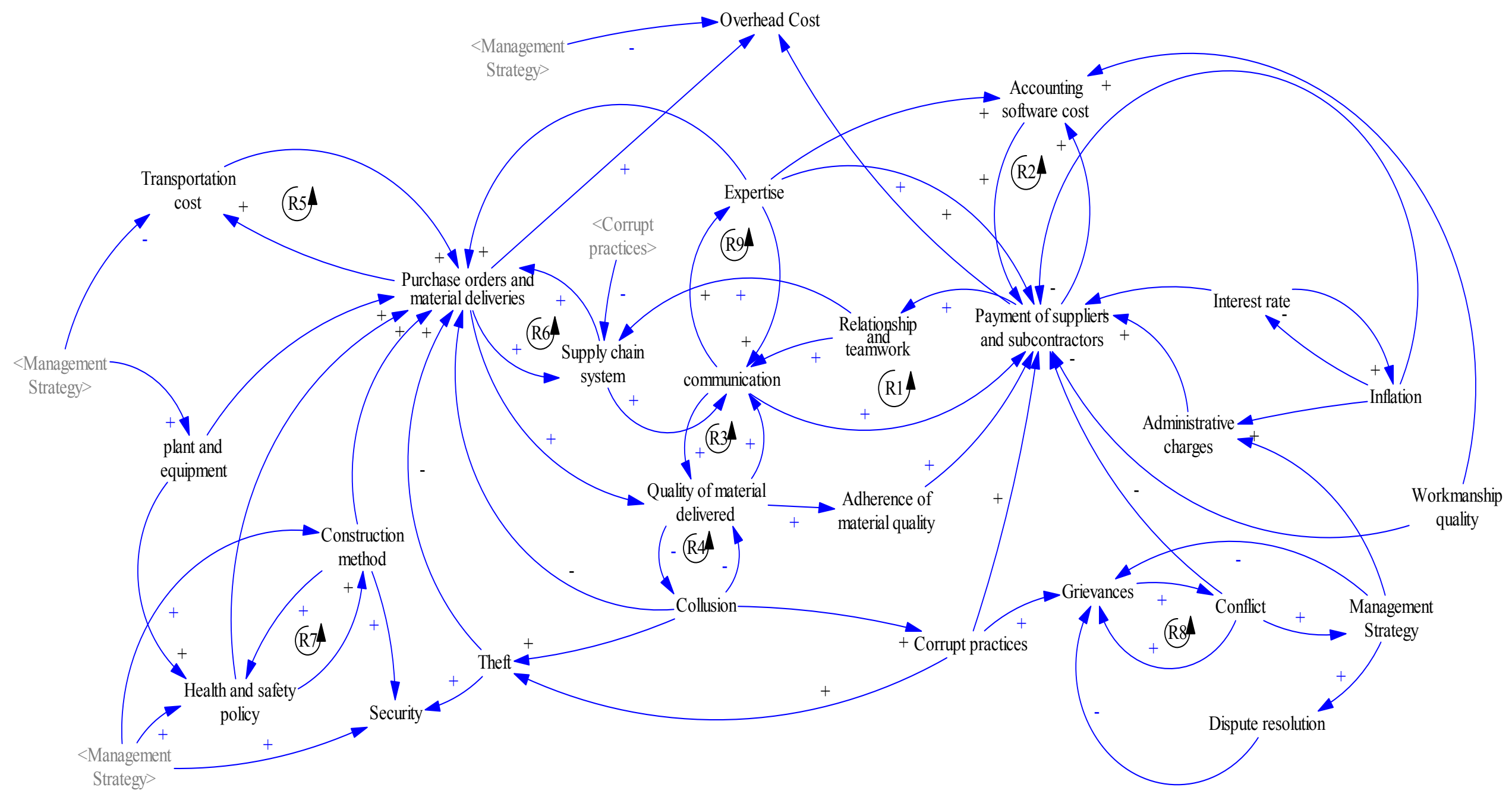

Figure 9. Systems thinking: Causal loop diagram for construction overhead costs 


\section{Tables}

Table 1: Contributory activities to waste in post-contract cost control

\begin{tabular}{|c|c|c|}
\hline Abbreviation & Meaning & References \\
\hline MESE & $\begin{array}{l}\text { Continual cost reduction of overhead cost of activities related to } \\
\text { mobilisation and equipment setup will keep the project cost within } \\
\text { budget }\end{array}$ & Nagapan et al. 2011; Nagapan et al. 2012 \\
\hline DRR & $\begin{array}{l}\text { Continual reduction of activities related to drawing reviews will } \\
\text { eliminate the unnecessary overhead cost }\end{array}$ & Nagapan et al. 2011; Nagapan et al. 2012 \\
\hline PI & $\begin{array}{l}\text { Continual reduction of overhead costs associated with preliminary } \\
\text { items of work such as site office, storage, security, electricity, water } \\
\text { supply, first aid and so on will eventually help the creation of more } \\
\text { profit and improve project delivery }\end{array}$ & $\begin{array}{l}\text { Vivan et al., 2015; Nagapan et al. 2012; } \\
\text { Hafez } 2015\end{array}$ \\
\hline CGPG & $\begin{array}{l}\text { Continual reduction of overhead costs related to construction cost } \\
\text { planning, general planning, and resource planning will create more } \\
\text { profit for the contractor }\end{array}$ & $\begin{array}{l}\text { Oyewobi et al. 2016; Lammoglia et al. } \\
\text { 2010; Cruz et al. } 2009\end{array}$ \\
\hline CVMI & $\begin{array}{l}\text { Ensuring activities related to construction variations are continually } \\
\text { minimised will create more profit for the contractor }\end{array}$ & $\begin{array}{l}\text { Ellström 2015; Lindén \& Josephson 2013; } \\
\text { Love et al. 2009; Danese et al. } 2012\end{array}$ \\
\hline PEOV & $\begin{array}{l}\text { Continual reduction of plant and equipment depreciation overhead } \\
\text { cost throughout the construction phase will keep the project cost } \\
\text { within budget }\end{array}$ & $\begin{array}{l}\text { Araujo et al. 2016; Selviaridis \& Norman } \\
\text { 2014; Emuze \& Julian Smallwood 2014; } \\
\text { Tran \& Carmichael } 2012\end{array}$ \\
\hline POM & $\begin{array}{l}\text { The cost of activities related to purchasing orders and material } \\
\text { deliveries can be reduced continually throughout the construction } \\
\text { phase to control the project cost for optimum profit. }\end{array}$ & $\begin{array}{l}\text { Tannock et al. 2007; Lammoglia et al. } \\
\text { 2010; Oyewobi et al. } 2016\end{array}$ \\
\hline PSL & $\begin{array}{l}\text { Overhead cost related to paying suppliers and subcontractors can be } \\
\text { reduced continually throughout the construction phase to keep the } \\
\text { project cost within budget }\end{array}$ & $\begin{array}{l}\text { Granja et al., 2005; Nagapan et al. 2011; } \\
\text { Nagapan et al. } 2012\end{array}$ \\
\hline
\end{tabular}


Table 2: Spearman's Rho correlation between the activities.

\begin{tabular}{|c|c|c|c|c|c|c|c|c|}
\hline$S / N$ & PEOVER (1) & MEsetup (2) & DRreviews (3) & CVMINI (4) & POM (5) & PSL (6) & CPGP (7) & $\begin{array}{l}\text { PI } \\
(8)\end{array}$ \\
\hline \multirow{2}{*}{$\begin{array}{l}1 \text { Rho } \\
\text { P-Value }\end{array}$} & 1 & 0.204 & -0.013 & 0.052 & -0.083 & 0.123 & 0.053 & $0.249^{* *}$ \\
\hline & & 0.017 & 0.884 & 0.553 & 0.337 & 0.154 & 0.540 & 0.004 \\
\hline \multirow{2}{*}{$\begin{array}{l}2 \text { Rho } \\
\text { P-Value }\end{array}$} & $0.204^{*}$ & 1 & 0.108 & -0.026 & 0.043 & -0.089 & -0.052 & 0.026 \\
\hline & 0.017 & & 0.214 & 0.766 & 0.619 & 0.303 & 0.546 & 0.765 \\
\hline \multirow{2}{*}{$\begin{array}{l}3 \text { Rho } \\
\text { P-Value }\end{array}$} & -0.013 & 0.108 & 1 & 0.002 & 0.144 & 0.001 & 0.160 & -0.043 \\
\hline & 0.884 & 0.214 & & 0.980 & 0.095 & 0.990 & 0.063 & 0.620 \\
\hline \multirow{2}{*}{$\begin{array}{l}4 \text { Rho } \\
\text { P-Value }\end{array}$} & 0.052 & -0.026 & 0.002 & 1 & -0.035 & $0.205^{*}$ & $0.251^{* *}$ & 0.025 \\
\hline & 0.553 & 0.766 & 0.980 & & 0.690 & 0.017 & 0.003 & 0.769 \\
\hline \multirow{2}{*}{$\begin{array}{l}5 \text { Rho } \\
\text { P-Value }\end{array}$} & -0.083 & 0.043 & 0.144 & -0.035 & 1 & $0.224^{* *}$ & $0.187^{\star}$ & 0.040 \\
\hline & 0.337 & 0.619 & 0.095 & 0.690 & & 0.009 & 0.030 & 0.647 \\
\hline \multirow{2}{*}{$\begin{array}{l}6 \text { Rho } \\
\text { P-Value }\end{array}$} & 0.123 & -0.089 & 0.001 & $0.205^{*}$ & $0.224^{* *}$ & 1 & 0.118 & 0.149 \\
\hline & 0.154 & 0.303 & 0.990 & 0.017 & 0.009 & & 0.172 & 0.084 \\
\hline \multirow{2}{*}{$\begin{array}{l}7 \text { Rho } \\
\text { P-Value }\end{array}$} & 0.053 & -0.052 & 0.160 & $0.251^{* *}$ & $0.187^{*}$ & 0.118 & 1 & 0.076 \\
\hline & 0.540 & 0.546 & 0.063 & 0.003 & 0.030 & 0.172 & & 0.382 \\
\hline \multirow{2}{*}{$\begin{array}{l}8 \text { Rho } \\
\text { P-Value }\end{array}$} & $0.249^{* *}$ & 0.026 & -0.043 & 0.025 & 0.040 & 0.149 & 0.076 & 1 \\
\hline & 0.004 & 0.765 & 0.620 & 0.769 & 0.647 & 0.084 & 0.382 & \\
\hline
\end{tabular}


Table 3: Multiple regression model

\begin{tabular}{ccccc}
\hline Model & R & R Square & $\begin{array}{c}\text { Adjusted R } \\
\text { Square }\end{array}$ & $\begin{array}{c}\text { Std. Error of } \\
\text { the Estimate }\end{array}$ \\
\hline 1 & 0.324 & 0.105 & 0.070 & 0.855 \\
\hline
\end{tabular}

Table 4: Residual values

\begin{tabular}{rlrrrrr}
\hline Model & & \multicolumn{1}{c}{$\begin{array}{c}\text { Sum of } \\
\text { Squares }\end{array}$} & df & Mean Square & F & \multicolumn{1}{c}{ Sig. } \\
\hline 1 & Regression & 11.073 & 5 & 2.215 & 3.032 & 0.013 \\
& Residual & 94.231 & 129 & 0.730 & & \\
\cline { 2 - 7 } & Total & $\mathbf{1 0 5 . 3 0 4}$ & $\mathbf{1 3 4}$ & & & \\
\hline
\end{tabular}


Table 5: Standardised Beta coefficients

\begin{tabular}{|c|c|c|c|c|c|c|}
\hline \multirow{2}{*}{\multicolumn{2}{|c|}{ Model }} & \multicolumn{2}{|c|}{$\begin{array}{l}\text { Unstandardized } \\
\text { Coefficients }\end{array}$} & \multirow{2}{*}{$\begin{array}{c}\text { Standardized } \\
\text { Coefficients } \\
\text { Beta }\end{array}$} & \multirow[t]{2}{*}{$\mathbf{t}$} & \multirow[t]{2}{*}{ Sig. } \\
\hline & & B & Std. Error & & & \\
\hline \multirow[t]{6}{*}{1} & (Constant) & 2.990 & 0.516 & & 5.801 & 0.000 \\
\hline & CPGP & 0.190 & 0.84 & 0.195 & 2.256 & 0.326 \\
\hline & PSL & 0.217 & 0.079 & 0.238 & 2.754 & 0.007 \\
\hline & CVMI & -0.078 & 0.084 & -0.080 & -0.931 & 0.354 \\
\hline & PI & 0.019 & 0.072 & 0.023 & 0.266 & 0.790 \\
\hline & PEOV & -0.121 & 0.085 & -0.122 & -1.415 & 0.160 \\
\hline
\end{tabular}




\section{Built Environment Project and Asset Management
BEPAM AUTHOR SUBMISSION CHECKLIST}

Date: 13th May, 2020

Manuscript ID:

Title:
BEPAM-10-2019-0100.R1

A systems thinking approach for incremental reduction of non-physical waste

\section{A) RELEVANCE TO BEPAM}

Does your paper MOSTLY focus on (Please click one box only):

Interface issues / links between Project Management and Asset Management of building and civil

engineering infrastructure

$\bigotimes$ Infrastructure Project Management

Infrastructure Asset Management

B) 'ScholarOne' Manuscript on-line Submission System

Yes / No

Remarks

\begin{tabular}{|lll|}
\hline \multirow{2}{*}{ Contact details } & \begin{tabular}{l} 
Provided Full name, Affiliation, E-mail address \& Postal \\
\cline { 2 - 3 }
\end{tabular} & Included $\underline{\text { ALL } \text { authors (including any co-authors)? }}$ \\
\hline Others & Note: You will need to complete all other 'required' fields in this system as well \\
\hline
\end{tabular}

\section{C) TITLE PAGE}

Completed ALL items on the page?

Yes

D) MAIN DOCUMENT (PAPER)

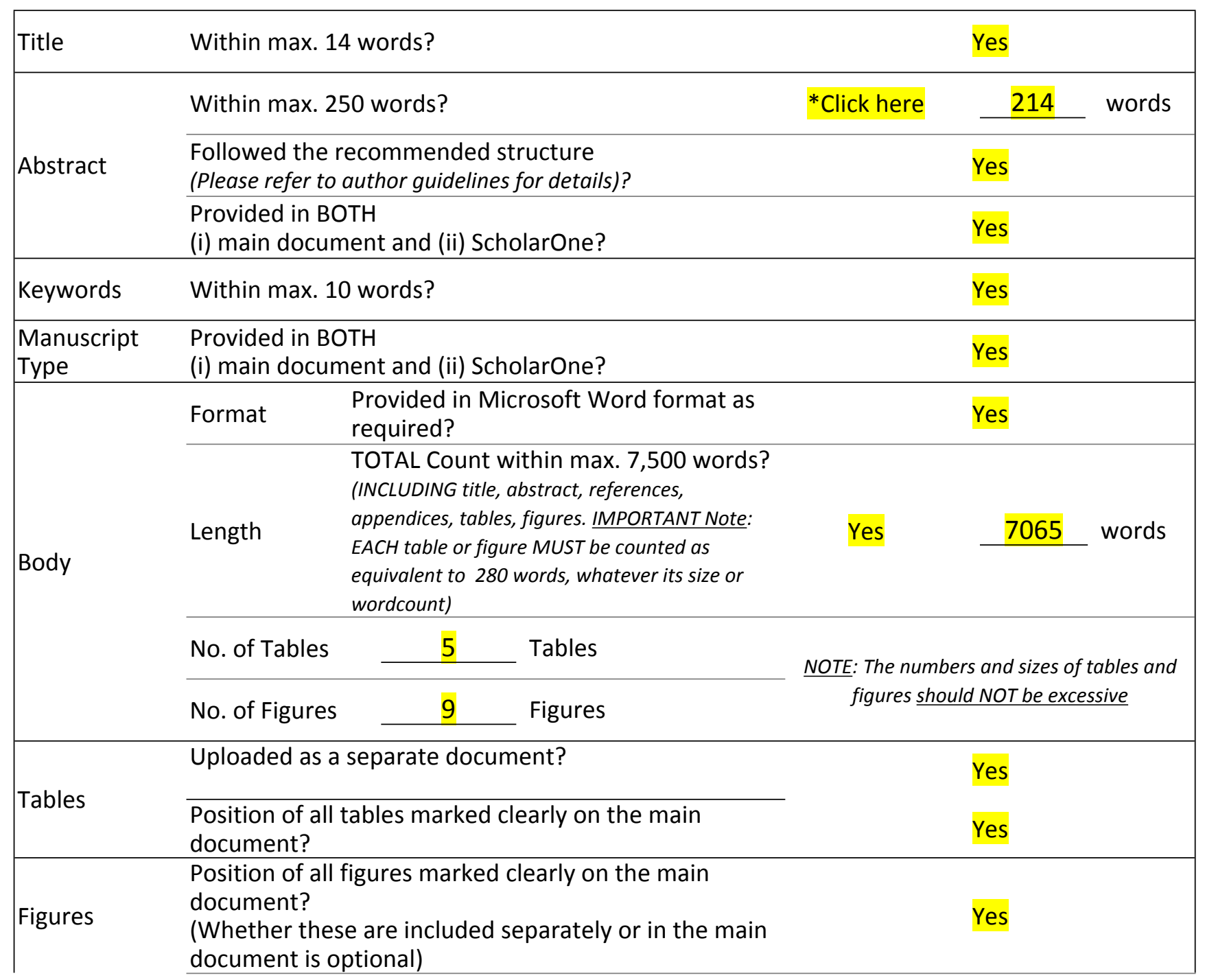




\section{E) PERMISSIONS}

Do you need to obtain permission for anything that you have not created yourself? (please refer to the following hyperlinks for details)

N.A.

- Author's permissions checklist: http://www.emeraldinsight.com/authors/writing/permissions checklist.doc

- Permission request form for the author to complete is located at:

http://www.emeraldinsight.com/authors/writing/permission request.doc

- General information on permissions is located at:

http://www.emeraldinsight.com/authors/writing/permissions.htm

*Please click each highlighted box above to make EACH selection 